Jarosław Fazan

Wydział Polonistyki, Uniwersytet Jagielloński

\title{
Spotkanie z Innym (człowiekiem i - niekiedy, być może - z Bogiem) w poezji Stanisława Barańczaka
}

\begin{abstract}
Nietowarzyskim odludkiem wprawdzie na zawsze zostanę, lecz klub ludzkości mnie przyjmie, notując $w$ aktach pobieżnie, że moim zajęciem byto coś, co, choć nie zakazane, jednak wskazane nie jest. I dobrze widziane - też nie.
\end{abstract}

Stanisław Barańczak, Strofa z Roberta Frosta

Sięgając po wiersze Stanisława Barańczaka z innych niż historycznoliterackie pobudek i dla innych poznawczych celów, możemy dostrzec w nich co najmniej kilka istotnych wątków. Twórczość Barańczaka czytana dzisiaj, czyli w kontekście twórczości poetów, którzy przyszli w ostatnich latach (powiedzmy, że dogodną perspektywą jest osiemnastolecie, które upłynęło od publikacji Chirurgicznej precyzji, ostatniego tomiku poety).

Po pierwsze - prowokuje do myślenia w sprawie zmiany (form) społecznej ważności poezji, szczególnie takiej, która pracuje w komunikacyjnym wymiarze języka lub nad nim, a zatem krytycznie podchodzi do językowego ustanawiania relacji międzyludzkich. Barańczak jest poetą bardzo konsekwentnie zajmującym się spotkaniem człowieka z innym człowiekiem, jednocześnie poszukującym różnych form obecności Innego, którego tożsamość wykracza poza człowieczeństwo. Po drugie - prowokuje do pytań o polityczne motywy i cele twórczości poetyckiej. Po trzecie i być może najważniejsze - skłania do refleksji nad relacjami międzyjęzykowymi, które stanowią nieuchronną perspektywę poezji zglobalizowanego świata (literackiego). Dzisiaj chciałbym 
się przyjrzeć pierwszemu z wyodrębnionych powyżej tematów. Być może dojdę do wniosków do pewnego stopnia istotnych dla ustanowienia drugiego (który zapewne łączy się jakoś z trzecim).

Dla Barańczaka poezja rodzi się w drastycznie negatywnej sytuacji ujawnienia nieskuteczności komunikacyjnej języka. Być może - jako sztuka - ma więc status swoistej perły, uformowanej $\mathrm{w}$ ranie pozostawionej przez boleśnie nieskuteczne zainicjowanie międzyludzkiego dialogu. Poecie przyświeca jednocześnie świadomość, że (oprócz języka poetyckiego) w miejscu nienawiązanej komunikacji rodzi się - a raczej wyradza - język perswazji i przemocy, mowa, w której nie tyle ktoś chce się z kimś innym spotkać, ile ustanowić go na swoich warunkach, określić w porządku władzy.

Mamy zatem do czynienia ze swoistym trójkątem: komunikacja - poezja - propaganda. Pierwsze ogniwo oznacza niespełniony cel języka, a w szczególności jego interpersonalnej roli; drugie do pewnego stopnia pocieszające dzieło, satysfakcjonujące estetycznie, dające zarazem złudną nadzieję na nieustanną korektę niedoskonałych form wypowiedzi; trzecie - instytucję wynikającą z odkrycia perswazyjnej mocy języka, dzięki której władza w najróżniejszych jej postaciach i wymiarach zastępuje porozumienie.

Ten stan rzeczy nakłada na poezję społecznie doniosłe zadania, stawia poetę w roli krytyka mowy publicznej, obnażającego językową przemoc. Trudna dziś do zrozumienia specyfika stosunków społecznych w PRL sprawiała, że prześladowany pisarz, którego twórczości nie publikowano, był swego rodzaju brutalnie zwalczanym partnerem władzy w grze o kształt publicznego języka; poezja krytyczna (lingwistyczna) była głosem sprzeciwu, kwestionującym ustanawiane przez propagandę wymiary świata. Przypomnijmy truizm: wiele utworów Barańczaka z lat 70. dekonstruuje język mediów, czyli prasy, radia i telewizji realnego socjalizmu. Celem jest odsłonięcie mechanizmu kłamstwa, deformującego obraz realnego doświadczenia, co z kolei skutkuje destrukcją społecznego obrazu człowieka. Relacja poezji i propagandy stanowi bilateralne starcie stron jednoznacznie określonych aksjologicznie. Twórczość ta jest zatem jednym z elementów walki politycznej przeciwko opresyjnemu ustrojowi, kwestionującemu elementarne 
prawa obywatelskie. Jednocześnie - po kilkudziesięciu latach od formowania się poetyckiego skrzydła opozycji, której fundamentem był koR - poezję Barańczaka można czytać jako pierwszą fazę nabywania poetyckiej świadomości beznadziejnego uwikłania w nieswój język. Dziś ten bilateralny, aż do końca lat 8o. klinczowy układ, uległ szczęśliwej komplikacji: jest dialogiem/sporem wielopodmiotowym. Myślę, że w znacznym stopniu dzięki krytycznej pracy Barańczaka i innych poetów jego formacji.

W utworach z lat 70. poeta konsekwentnie podejmuje walkę (to patetyczne określenie pasuje do stylistyki tamtej epoki) o oczyszczenie języka, o oswojenie go i podporządkowanie prawdzie ludzkiego doświadczenia. Ta nieufna wiara w uwolnienie i odzyskanie mowy wydaje się z dzisiejszej perspektywy pięknie naiwna. Dla poezji naszych czasów jej anonimowa sztuczność mowy i nieodwracalne uwikłanie w klisze stanowią poziom zero twórczości. Dla poezji nie ma już chyba nadziei na odzyskanie własnego języka; gra/walka o wolność toczą się na innym poziomie, jednakże zasadę tych zmagań określił m.in. Barańczak, ustanawiając poezję jako sztukę dekonstrukcji propagandy. Dzisiejsze walki, gry i zabawy poetów z obcymi językami, których celem jest kreowanie indywidualnej dykcji, zaczynają się przecież od zderzenia z mową medialną, od prób przezwyciężenia jej wszechmocy.

Barańczak należy do poetów odsłaniających tragiczny sposób istnienia języka, który nie jest i być nie może tym, czym być powinien; nigdy nie osiągnie celu, do którego został powołany. Poezja w początkowej fazie twórczości autora Korekty twarzy miała być swoistym mechanizmem ujawniającym wykolejenie języka, a jednocześnie systemem terapeutycznym - leczniczym i profilaktycznym. Miała być przede wszystkim sztuką korekty, dystansującą się od estetycznych satysfakcji. Motywacje i cele sterujące tym mechanizmem były w tradycyjnym sensie humanistyczne, chodziło o poprawę kondycji człowieka 2. połowy xx wieku, zniewolonego przez totalitaryzm, perfekcyjnie posługujący się propagandą. Bohater wczesnej poezji Barańczaka, którego najpełniejszym wcieleniem jest N.N. ze Sztucznego oddychania, to figura człowieka w językowym wymiarze bezskutecznie przedzierającego się przez propagandę do komunikacji; jego połowicznym 
wyzwoleniem okazuje się jednak poezja. W niej nie da się nawiązać realnego kontaktu z innym człowiekiem z krwi i kości, można tylko i aż - próbować zbliżać się do tego niemożliwego spotkania, nastrajać język do upragnionego dialogu.

Podstawowe zadanie poezji jest więc negatywne: obnażanie i kompromitowanie propagandy stanowi jej powinność. Oczywiście na pierwszy plan wysuwają się chwyty odsłaniające kłamstwo języka władzy, ale za tym kryje się coś, co można nazwać systemem antropologii lingwistycznej. Dekonstrukcja oficjalnego języka jest jednocześnie demontażem fałszywego obrazu człowieka, fikcyjnej postaci utworzonej na potrzeby politycznej perswazji, reprezentującej absurdalny wzorzec postępowania dla prawomyślnych obywateli „socjalistycznej ojczyzny”. Barańczak z jednej strony ujawnia jego papierowość, z drugiej - diagnozuje destrukcyjny wpływ na realną egzystencję ludzi lat 6o. i 70. W kontrze do tych negatywnych zabiegów rysuje się figura człowieka autentycznego. Używając myślowego skrótu, można powiedzieć, że te lingwistyczne gry przypominają Białoszewskiego mechanizm językowej redukcji zafałszowania i nierzeczywistości, poprzez który mistrz młodości Barańczaka ustanawiał przestrzeń jednostkowej wolności epoki totalitarnej.

Obrazem rytuału propagandowego, ustanawiającego człowieka, którego nie ma, figurę antropologicznych potrzeb totalitarnej władzy, jest wiersz Zbiorowy entuzjazm (z tomu Ja wiem, ze to niestuszne). Ujawnia on grupe „ludzi, porwanych zbiorowym entuzjazmem, którzy potrafią napisać list do redakcji” [wz: 177]', którzy okazują się fikcyjnymi bohaterami prasowej ustawki, mającej wykazać społeczną akceptację dla prześladowań opozycji politycznej. Wiersze z lat 70. w znacznej części opierają się na misternych grach językowych, skoncentrowanych na kompromitowaniu zakłamania. Barańczak wchodzi w rolę poety-terapeuty języka: próbuje przywracać mu ewangeliczną przejrzystość. Przypomnijmy, iż ten „niereligijny” wówczas poeta otwiera swój tomik Sztuczne oddychanie (1974) cytatem ze św. Mateusza: „Lecz niech

1 Wszystkie cytaty z utworów Stanisława Barańczaka lokalizuję w Wierszach zebranych (skrót: wz). 
mowa wasza będzie / tak, tak, nie, nie. / A co nadto więcej jest, / od złego jest” [wz: 115].

Po nim następuje słynny wiersz Określona epoka, który w lustrzanym odbiciu pokazuje destrukcję inicjatora i nadawcy twórczości epistolarnej, opisanej w Zbiorowym entuzjazmie. Monolog liryczny jest tutaj parodią przemówienia polityka (być może zabawa słówkiem „nieprawda”, refrenicznie powtarzanym przez mówcę, jak nieświadoma autokompromitacja, wskazuje na konkretną osobę, ówczesnego pierwszego sekretarza KC PZPR Edwarda Gierka). Ze słów dobieranych na zasadzie żonglerki sloganami, nieudolnie maskującymi przemoc, wyłania się nie-ludzki wizerunek podmiotu, zredukowanego do pozbawionych indywidulanego wyrazu słów i gestów. Niezdolność do realnej komunikacji rodzi przemoc, której ofiarami są zarówno ci, którzy ją wywierają, jak i ci, przeciw którym jest ona skierowana. Ze sfingowanymi autorami listów do redakcji, z partyjnym mówcą nie można nawiązać kontaktu; ich inność jest właściwie nieludzkością, ponieważ uniemożliwia nawiązanie rozmowy.

Zapisem formowania się relacji z innym, którą można nazwać nie-spotkaniem, jest etyczno-polityczny wiersz To mnie nie dotyczy. Tytułowe stwierdzenie jest powtarzanym w kółko, kompulsywnie, odcięciem się od scen, w których obserwowani ludzie dzielą się na wyraźnie wyodrębnione grupy oprawców i ofiar. Powtarzana deklaracja odcięcia się to wyraz lęku, a zarazem niepewności, poczucia winy i bezradności, które skumulowane stawiają pod znakiem zapytania człowieczeństwo. Kwestionują je w takim samym stopniu zarówno przywołane w tekście akty przemocy, jak i deklarowana obojętność obserwatora. Spojrzenie dzisiejsze, wolne od ówczesnych namiętności, nakierowane na inne aktualia, pozwala dostrzec w tych utworach cechy uniwersalne, być może przede wszystkim krytykę języka: degradującego, redukującego perspektywę człowieka do bardzo wąsko, partykularnie pojętej egzystencji jednostkowej, skupionej na zachowaniu życia i tzw. świętego spokoju. Granice świata są granicami języka, perspektywa epistemologiczna jest tutaj spójna z etyczną.

Kolejnym obrazem rozpadu relacji, zaniku związku z innym jest wiersz Na śmierć przyjaciela. Ten „antytren” jest symptoma- 
tycznym wyrazem obcości w stosunku do kogoś do niedawna bliskiego, kto dał się zapędzić w wąski horyzont swoich spraw. Tytułowa metaforyczna śmierć (cywilna, moralna, ludzka) jest efektem zdrady, przejścia na złą stronę, tak radyklanie wyobcowującego, że najlepszym dla niego określeniem jest właśnie „śmierć”. Inność tej klasy ludzi ujmowana jest w wierszach z 2. połowy lat 70. ambiwalentnie. Z jednej strony są nie mniej, a może nawet bardziej sterroryzowani strachem od tych, którymi rządzą (Ci mężczyźni, tak potężni), z drugiej strony podmiot, kiedy zbliża się do postaci bliskiej samemu autorowi (jak w wierszu pod znaczącym tytułem A tak niewiele brakowało), przyznaje, że sam nie różni się od nich tak bardzo.

Przestrzeń bloku i osiedla złożonego z wielu bloków wydaje się miejscem stworzonym do codziennego praktykowania odczłowieczającej obcości pomiędzy ludźmi. Pewna wokalistka z lat 80. śpiewała, że w „domach z betonu nie ma wolnej miłości”; poezja Barańczaka przekonuje, że blok i blokowisko są laboratorium antropologicznym, w którym człowieka nagina się do formy odpowiadającej potrzebom propagandy. Z punktu widzenia poety przestrzeń ta staje się językowym polem walki o ocalenie człowieka. Poszukiwania swoistej „blokowej” duchowości to jeden z jej wymiarów. W cyklu Kątem u siebie (Wiersze mieszkalne) pojawia się zabawny utwór niewątpliwie religijny - Czas skończyć z takimi, w którym nieprzychodzący, a uporczywie wzywany fachowiec, mający naprawić liczne usterki blokowego mieszkania, jest figurą Boga odpowiedzialnego za niedoskonałość „własnościowego życia”: „i jak On chce, żebym w Niego wierzył, / ten niesolidny rzemieślnik / bujający w obłokach; [...] // czy On sobie wyobraża, że jest moim Panem?” [wz: 220].

Decyzja uznania blokowych realiów za figurę uniwersalnych właściwości boskiego dzieła, jakim jest ludzki świat, umożliwia Barańczakowi ujęcie go przez pryzmat irytujących i wszechobecnych usterek (biorąc pod uwagę rozwój blokowisk w epoce Gierka, były to realia dotkliwie znane dużej części społeczeństwa naszego

2 W interpretacji tego utworu podążam za jego ujęciem dokonanym przez Krzysztofa Biedrzyckiego [1995: 259-269]. 
kraju). Spotkanie (a raczej, rzecz jasna, niespotkanie) z Bogiem jest znakiem niedoczekania się na „niesolidnego rzemieślnika” powołanego do usuwania defektów masowej produkcji świata z wielkiej płyty. Co sądzić o tej podwójnej figurze jednoczesnego uwznioślenia (betonowej egzystencji) i umniejszenia (boskiej istoty)? Poeta szuka idiomu „duchowości z wielkiej płyty”, w którym powaga i niepowaga, groza i groteska łączą się spoiście, budując pojemny system. To zresztą będzie stała właściwość poezji Barańczaka: świat dany człowiekowi, niedoskonały, a nawet, nieprzyjazny czy wręcz - wrogi, jest miejscem, z którym trzeba się pogodzić, w którym należy się zadomowić, wciąż krytykując go i stale ponawiając próby naprawy. Nie przerywając krytyki, należy próbować odnaleźć w nim miejsce życia. Obcość świata pełnego usterek ma wymiar prześmiewczo metafizyczny $y^{3}$. Jednocześnie - upragniona i nieosiągalna obecność hydraulika, ślusarza, murarza - zostaje sprowadzona do boskiej nieuchwytności. W tym samym mniej więcej czasie powstawały wiersze „blokowe” Białoszewskiego (zebrane w tomie Odczepić się), podobnie - groteskowo - ujmujące realia życia w wielkiej plycie, podobnie - szukające niesztucznego patosu ,jedenastopiętrowego bytu na mur-beton”. On rodzi się z brutalnego ograniczenia, z konieczności zaakceptowania zupełnie obcych form podstawowych czynności życiowych (Skoro już musisz krzyczeć, rób to cicho). Takie warunki egzystencji nieustanie naruszają intymność, wymuszając niechcianą bliskość, w gruncie rzeczy oddalają ludzi od siebie, uszczelniają granice prywatności, rujnują możliwość spotkania zbyt szybkim odsłonięciem trywialnych i odstręczając cech bliźnich. To doświadczenie jednoczesnego wyobcowania i nadmiernego zbliżenia - zagraża wysokim pojęciom humanizmu. W dość perwersyjnym wierszu Gdyby nie ludzie z Dziennika zimowego wprost mówi się: „Gdyby nie ludzie, gdyby nie istnieli / [...] o ile łatwiej by się mówiło nic co ludzkie nie jest" [wz: 229].

3 Można odnieść wrażenie, iż w cyklu „betonowym” Barańczak rozstaje się ze wzniosłą utopią budowlaną zawartą w programie Tadeusza Peipera, stanowiącym dla młodego poety istotny układ odniesienia. Wzniesione w PRL-u domy nie są ani doskonałe, ani - mimo rozmiaru - wzniosłe. Budowa w odniesieniu do nich stanowi co najwyżej parodię kluczowego pojęcia w systemie estetycznym autora Tędy. 
Właściwie z powodu użycia niedokończonej frazy Terencjusza wiersz ten jest sui generis manifestem antyhumanizmu, choć jego mizantropia, a nawet pewna ksenofobia, wydają się wynikiem radyklanego zagęszczenia relacji międzyludzkich w epoce blokowisk i masowej (lecz pozornej) komunikacji, dehumanizacji, zamieniającej pojedynczego człowieka w cząstkę masy. Warto jednak dodać, że obraz ludzi współczesnych nadawcy ujawnia jego wyższościowy, ironiczny dystans, niekoniecznie oczywisty. Można się w nim również, rzecz jasna, dopatrzeć akcentów pedagogicznych. Wyliczanie rozmaitych negatywów realnych ludzi (łupież obok paranoi, wyszmelcowana teczka obok antysemityzmu) ma je chyba korygować. To wiersz podobny do oświeceniowej satyry: gorzki i zabawny zarazem, jawnie dydaktyczny. Ukazuje samotnego w tłumie poetę-moralistę, patrzącego z góry (i wcale niedobrotliwie) na ludzkie przywary, niekryjącego obcości, pogardy i wstrętu. A przede wszystkim chyba - braku ciekawości, bo jak stwierdza: miałby zapewne lepszy do nich stosunek, "gdyby wcale / nie trzeba ich było poznawać”.

Ten pozornie prosty wiersz ujawnia tragiczną ambiwalencję humanizmu: jest możliwy pod warunkiem nieobecności ludzi, ponieważ realni ludzie są zniechęcająco inni od wyobrażeń o ich właściwym życiu. (Trudno się obronić przed myślą, że poeta poddany totalitarnej presji przejmuje restrykcyjny sposób reagowania/myślenia). W innym utworze z tego samego cyklu (14.12.79: Wieczór autorski [wz: 235]) funkcjonariusze, będący sprawnym narzędziem systemu opresji, skrócili swoją „,wizytę” w domu poety, czytającego "nielegalne” utwory, ponieważ spieszyli się na emisję filmu w telewizji, co uzasadnili sentencją, że „człowiek jest tylko człowiekiem". Ta likwidacja, czy raczej kapitulacja humanizmu, zawarta w potocznej, zbanalizowanej frazie, obrazuje radykalne wyczerpanie się tradycyjnego języka, ukazuje niemożność spotkania realnego człowieka, albowiem uwikłanie w wyobcowany, zawłaszczony przez propagandę język deformuje nieodwracalnie relację między ludźmi, buduje nieprzekraczalną właściwie barierę.

W późniejszych latach poeta ciągle szuka możliwości spotkania z drugim człowiekiem, ale realia propagandowej destrukcji przestrzeni komunikacji, uniemożliwiającej spotkanie z innym, 
zastępują problemy odmiennej natury. Wyjazd do Ameryki to nie tylko zmiana językowej przestrzeni, przenosząca obcość na inny poziom, ale też mocniejsze wejście $\mathrm{w}$ dialog z innymi, głównie angielskojęzycznymi poetami. Oczywiście twórczość przekładowa od samego początku właściwie stanowi istotną część poezji Barańczaka; na emigracji jednak rozwija się bujniej, niekiedy spychając poezję oryginalną na drugi plan. Właściwie jednak dobrze się składa, że partnerami poetyckich gier intertekstualnych stają się częściej inni poeci niż pierwsi sekretarze i propagandyści. Wówczas spotkanie $\mathrm{z}$ innym dokonuje się $\mathrm{w}$ przestrzeni zapośredniczonej często przez tłumaczonego lub przywoływanego poetę. I okazuje się, że spotkanie takie, prawem poetyckiej iluzji zapewne, stwarza szansę nieosiągalnej wcześniej komunikacji. Przede wszystkim inny konkretyzuje się i indywidualizuje, wyzwala się z negatywnych układów „organizmu zbiorowego” ustanawianego przez propagandę.

Cały cykl Podróży zimowej jest niezwykle misterną konstrukcją poetycko-muzyczną, rozwijającą rozmaite warianty religijnych i egzystencjalnych spotkań i nie-spotkań z innymi. Samochodowe utwory z tego tomu lączą przeplatające się motywy i subtelne nawiązania, ich nośnikami bywają inni poeci. W wierszu $\mathrm{X}^{* * *}$ [Zastyga na poboczu dodge] [wZ: 399] pędzący podmiot widzi sikającego przy drodze mężczyznę, którego „parujący mocz dziurawi śnieg i ciszę"; ostatnie słowo przywołuje w jego świadomości fragmenty Dziewczyny Bolesława Leśmiana, ujawniające grozę absolutnej pustki, totalnego osamotnienia kogoś, kto dążył do upragnionego spotkania. Dwie linijki z Leśmiana: „I była zgroza nagłych cisz $[\ldots] ”$ oraz „A ty z tej próżni czemu drwisz [...]” nie ujawniają ty tułowej bohaterki przywoływanego wiersza. Inna, amerykańska postać „dziewczyny” pojawia się nieoczekiwanie w Xx ogniwie cyklu ${ }^{* * *}$ [Stojąc na czerwonym świetle...]. Jest żywa, obecna, widoczna "Za okienkiem bocznym hondy - / w drzwiach wciśnięty zamka spust, / [...] Włosy blond i profil chłodny: / Poprawianie szminką ust" [wZ: 411]. Na to momentalne nie-spotkanie, którego nie sposób nazwać nawet dziwacznym spełnieniem marzeń dwunastu Leśmianowskich braci, podmiot reaguje jednak radosnym na pozór, pełnym niedowierzania 
zawołaniem: „A więc jesteś?”, przeciętym, złamanym natychmiast samodopowiedzeniem: „No to bądź”. Jednym z tematów Podróży zimowej jest smutek cielesnego, materialnego urzeczywistnienia pragnień kiedyś niemożliwych do spełnienia. Obecność dziewczyny, nawet złowionej spojrzeniem, oznacza jedynie równoległe spadanie w dwu otchłaniach, „każde w swój osobny mrok”. A zatem spotkanie $\mathrm{z}$ innym, czy raczej inną, w przestrzeni wyznaczonej przez przywołanego poetę, odsłania odmienny niż w wierszach peerelowskich wymiar obcości. Pojawia się szansa intymniejszego kontaktu, uwolnionego z propagandowej formy; okazuje się jednak, że i tym razem poezja może co najwyżej zarysować granicę, linię brzegową nieosiągalnej komunikacji.

Podobna sytuacja ma miejsce także w wierszach z Chirurgicznej precyzji, w których walka o spotkanie z Innym, człowiekiem i Bogiem, dokonuje się w najintymniejszej z ludzkich przestrzeni, jaką ustanawia umieranie. Spotkanie z innym ma charakter tragiczny, bowiem zawarta więź (komunikacja wszak wywodzi się od komunii) napotyka nieprzekraczalną barierę, jaką jest pojedynczość odchodzenia, absolutna samotność śmierci (Płakała w nocy...).

\section{Bibliografia}

Barańczak Stanisław (2006), Wiersze zebrane, as, Kraków. (Skrót: wz) Biedrzycki Krzysztof (1995), Świat poezji Stanisława Barańczaka,

Universitas, Kraków.

Jarosław Fazan

A meeting with an Other (a person and - sometimes, maybe - with God) in Stanisław Barańczak's poetry

This outline touches upon the issue of the (failure of) communication as a challenge to modern poetry about political and anthropological topics. The author is interested in how Stanisław Barańczak's poetry presents a meeting between people which is, first and foremost, a relationship with otherness describing the identity of an individual and their difference from the others. This relationship is often linked to power and violence that use the language of propaganda as a tool that poetry attempts to deconstruct 
and discredit. A unique extension of the human-human relationship is a search for a relationship with an entity other than human, which the poetry of the author of Journey in Winter (Podróż zimowa) presents as possible, yet actually unachievable.

Keywords: poetry; communication; propaganda; violence; Other.

Jarosław Fazan - urodzony w 1966 roku, historyk literatury xx wieku, nauczyciel akademicki, edytor Pism Tadeusza Peipera (opracował dwa tomy - wraz z Katarzyną Fazan: Wśród ludzi na scenach i na ekranie oraz Gabriela Zapolska jako aktorka). Autor książek Ale Ja nie Bóg. Kontemplacja i teatr w dziele Mirona Białoszewskiego (1999) i Od metafory do urojenia. Próba patografii Tadeusza Peipera (2010); współredaktor tomów: Żagary. Środowisko kulturowe grupy literackiej (2009), Na pograniczach literatury (2012), Formacja 1910: biografie równoległe (2013). Wraz z Krzysztofem Zajasem redaguje serię Polish Studies - Transdisciplinary Perspectives, ukazującą się nakładem wydawnictwa Peter Lang. Kieruje Ośrodkiem Badań nad Awangardą utworzonym na Wydziale Polonistyki uJ. 
